\title{
ENTREPRENEURIAL POTENTIAL IN ENGINEERING AND BUSINESS COURSES WHY WORRY NOW?
}

\author{
Aurora A.C. Teixeira \\ INESC Porto, Faculdade de Economia do Porto (FEP), CEMPRE, Universidade do Porto, \\ ateixeira@fep.up.pt; aurora.teixeira@inescporto.pt
}

\begin{abstract}
In this paper we analyze the magnitude of this propensity in engineering and economics/business courses. The reason for such focus is that traditionally these courses are viewed as the ones concentrating individuals that are more likely to create new ventures. The empirical results, based on a large-scale survey of 2430 final-year students, reveal that no statistical difference exists in entrepreneurial potential of economics/business and engineering students, and that these two latter groups have lower entrepreneurial potential than students from other courses. This result proves to be quite unfortunate given the focus that previous studies have placed on these two majors, and the fact that a substantial part of entrepreneurial education is undertaken in business and engineering schools.
\end{abstract}

\section{INTRODUCTION}

Several recent trends have sparked renewed interest in entrepreneurship: the European Commission's recognition that "[e]ntrepreneurial activity underlies the creation of wealth and employment (...) Europe needs more entrepreneurs, to raise the number of competitive enterprises in Europe" (European Commission, 2000); the discontent of many employees with the structure of Europe's large businesses; emerging business opportunities due to technological, ecological, and social changes (for example, computerization, pollution, energy shortages, the increase in two-worker families, the growing elderly population, and geographical shifts in population) (McFarlane, 1981); and the problems of current European and Portuguese businesses related to low productivity, lack of innovative flexibility, and increased international competition (GEE, 2005).

The idea of becoming an entrepreneur is more and more attractive to students because it is seen as a valuable way of participating in the labor market without losing one's independence (Martínez et al., 2007).

The most common values amongst graduates facing the new labor market are linked to those of the self-employed: independence, challenge and self-realization (Lüthje and Franke, 2003).

While there has been significant research on the causes of entrepreneurial propensity (Greenberger and Sexton, 1988; Learned, 1992; Naffziger et al., 1994; Brandstatter, 1997), only a limited number of studies have focused on the entrepreneurial intent among students. Those that exist tend to focus on US and UK cases and are mainly restricted to small samples of business related majors. 
While new venture opportunities exist within nearly all academic disciplines (e.g., graphic arts, nursing, computer science), the majority of entrepreneurship initiatives at universities are offered by business schools (Ede et al., 1998; Hisrich, 1988) and for business students (e.g., Roebuck and Brawley, 1996). In fact, most studies that have been conducted to explore entrepreneurial intent among university students have focused on business students (e.g., DeMartino and Barbato, 2002; Ede et al.; Hills and Barnaby, 1977; Hills and Welsch, 1986; Krueger et al., 2000; Lissy, 2000; Sagie and Elizur, 1999; Sexton and Bowman, 1983). However, Hynes (1996) advocated that entrepreneurship education can and should be promoted and fostered among non-business students as well as business students. Consequently, if a goal in designing entrepreneurial programs is to assist students within and outside the business school, it is important to understand the similarities and differences between business school students and their non-business counterparts. In the present paper we examine the entrepreneurial characteristics among students of business/economics and engineering and the relationships between academic major and interest in entrepreneurship. The focus is thus on two groups of students: business/economics majors and engineering majors.

Despite the heterogeneity of sampling methods and target population, the existing studies on the issue (see Table 1) report that, on average, one quarter of students surveyed claimed that after their graduation they would like to become entrepreneurs (starting their own business or being self-employed).

It is not widely known (and is currently subject to intense debate) whether contextual founding conditions or personal traits drive the students' career decision towards selfemployment (Luthje and Franke, 2003). In order to design effective programs, policy makers have to know which of these factors are decisive (Scott and Twomsey, 1988). In the next section we discuss this issue in greater detail.

The paper is structured as follows. In the following section a brief review of the literature on students' entrepreneurial intentions is presented. Then, in Section 3, we detail the methodology and describe the data. The estimation model and results are presented in Section 4. Some conclusions are summarized in Section 5.

\section{STUDENT ENTREPRENEURSHIP POTENTIAL. A BRIEF REVIEW OF THE LITERATURE}

The traditional mainstream view of the entrepreneur is as a 'risk-taker' bringing different factors of production together. The Austrian school takes a more dynamic perspective with entrepreneurship crucial for economic development and as a catalyst for change. In particular the Schumpeterian entrepreneur is an innovator who introduces new products or technologies. Frequently the notion of entrepreneurship is associated with predominant characteristics such as creativity and imagination, self-determination, and the abilities to make judgmental decisions and coordinate resources (Henderson and Robertson, 1999).

Adapting Carland et al.'s (1984: 358) definition of “entrepreneur", we define 'potential entrepreneur' as "an individual [final year student] who [admits] establish[ing] and manag[ing] a business for the principal purposes of profit and growth".

According to several authors (e.g., Carland et al., 1984; Hatten and Ruhland, 1995), entrepreneurs are characterized mainly by innovative behavior and employment of strategic management practices in the business.

A relevant body of literature on entrepreneurial activities reveals that there is a consistent interest in identifying the factors that lead an individual to become an entrepreneur (Martínez et al., 2007). Several pieces of evidence show that these are 
similar, with the most frequent analyzed as age, gender, professional background, work experience, and educational and psychological profiles (Delmar and Davidsson, 2000).

Broadly, three factors have been used to measure entrepreneurial tendencies: demographic data, personality traits (Robinson, 1987), and contextual factors (Naffziger et al., 1994). Demographic data (gender, age, region) can be used to describe entrepreneurs, but most of these characteristics do not enhance the ability to predict whether or not a person is likely to start a business (Hatten and Ruhland, 1995). The second method of assessing entrepreneurial tendencies is to examine personality traits such as achievement motive, risk taking, and locus of control. McClelland (1961) stressed need for achievement as a major entrepreneurial personality trait, whereas Robinson (1987) asserted that self-esteem and confidence are more prominent in entrepreneurs than the need for achievement. Several authors (e.g., Naffziger et al., 1994), however, argue that the decision to behave entrepreneurially is based on more than personal characteristics and individual differences. Accordingly, the interaction of personal characteristics with other important perceptions of contextual factors needs to be better understood.

Dyer (1994) developed a model of entrepreneurial career that included antecedents that influenced career choice. Antecedents to career choice included individual factors (entrepreneurial traits), social factors (family relationships and role models), and economic factors. This author asserted that children of entrepreneurs are more likely to view business ownership as being more acceptable than working for someone else. Baucus and Human (1995) studied Fortune 500 firm retirees who started their own business and found that networking, their view of departure, and prior employment experience positively affected the entrepreneurial process. Carroll and Mosakowski (1987) asserted that children with self-employed parents likely work in the family firm at an early age. That experience, coupled with the likelihood of inheriting the firm, led the individuals to move from a helping situation to full ownership and management. Van Auken et al. (2006) found that the importance of family owned businesses and the influence of family (including parental role modeling) in Mexico suggests that Mexican students may be more interested in business ownership than US students. Earlier, Scott (1988) also found that children of self-employed parents have a much higher propensity to become self-employed themselves. He conjectured that perhaps the influence of parents was twofold: first, as occupational role models, and second, as resource providers.

In general, the results indicate that being a man aged between 25 and 40 with selfemployed parents, a higher education degree, need for achievement, risk taking propensity, and preference for innovation are the factors that favor the decision to undertake entrepreneurial activities (Storey, 1994; Reynolds, 1997; Stewart et al., 1998; Delmar and Davidsson, 2000; Martínez et al., 2007).

In Section 4, for the selected students, we assess which of the three groups of determinants of entrepreneurial intention - demographic, psychological, and contextual emerges as more relevant. Before embarking on this analysis, the next section details and describes the methodology and data gathered.

\section{METHODOLOGY AND DESCRIPTIVE STATISTICS}

A questionnaire was developed and pre-tested during spring 2006. Final year students of all subjects at the largest Portuguese university were surveyed regarding their entrepreneurial potential. The survey was mainly implemented in the classroom, but when that was impossible (some final year students did not have classes as they were in internship training) the survey was implemented through an online inquiry. The final year 
students totaled 3761 individuals, spread over 60 courses, offered by 14 schools/faculties. The survey was carried out from September 2006 up to March 2007. A total of 2430 valid responses were gathered, representing a high response rate of $64.6 \%$. Of these responses, 490 were from economics and business students and 495 from engineering (totaling 985 individuals). The response rates of these groups were, respectively $51.6 \%$ and $71.7 \%$.

The questionnaire contained 17 questions, which include specific demographic descriptors (such as gender, age, student status, and region); participation in extra curricula activities, professional experience, academic performance, and social context; statements designed to measure fears, difficulties/obstacles and success factors concerning new venture formation to which students responded using a 5-point Likert scale. The entrepreneurial potential was directly assessed by asking students which option they would choose after completing their studies: starting their own business or being exclusively self-employed; to work exclusively as an employee; to combine employment and self-employment.

Analyzing responses by courses within Economics and Engineering Schools we observe that almost $35 \%$ are from Economics course and $15 \%$ from Business. In engineering the most representative courses are Computing, Electronics and Civil engineering, encompassing, respectively, $11 \%, 9 \%$ and $8 \%$ of the total number of selected students.

On average, 24\% of economics/business and engineering students surveyed claim that they would like to start their own business after graduation. Metal and Industrial and Management Engineering are the most entrepreneurially driven courses with over $30 \%$ of students desiring to start a new venture. It is interesting to note that, in general, male students are more entrepreneurially driven than their female counterparts - $29 \%$ of male students would like to start their own business after graduation, whereas in the case of female students, that percentage is around $18 \%$. Differences by course are particularly acute in Mining, Economics and Computing. In Business and Civil engineering, male and female students have a similar entrepreneurial propensity.

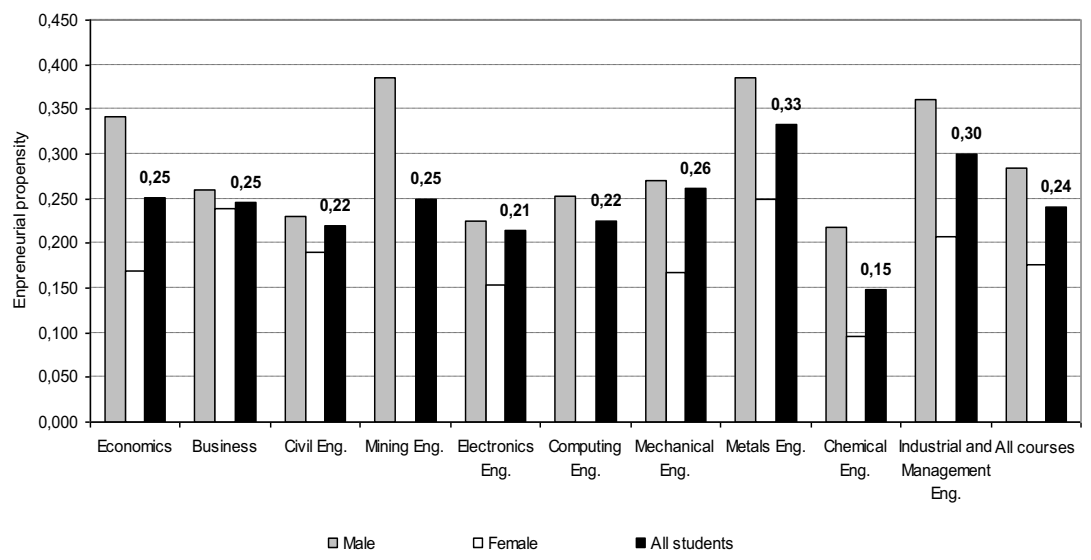

Figure 1. Entrepreneurial propensity by gender and courses

Excluding Industrial \& Management Engineering, in general, older students (over 26 years old) are more entrepreneurial than their younger colleagues. 


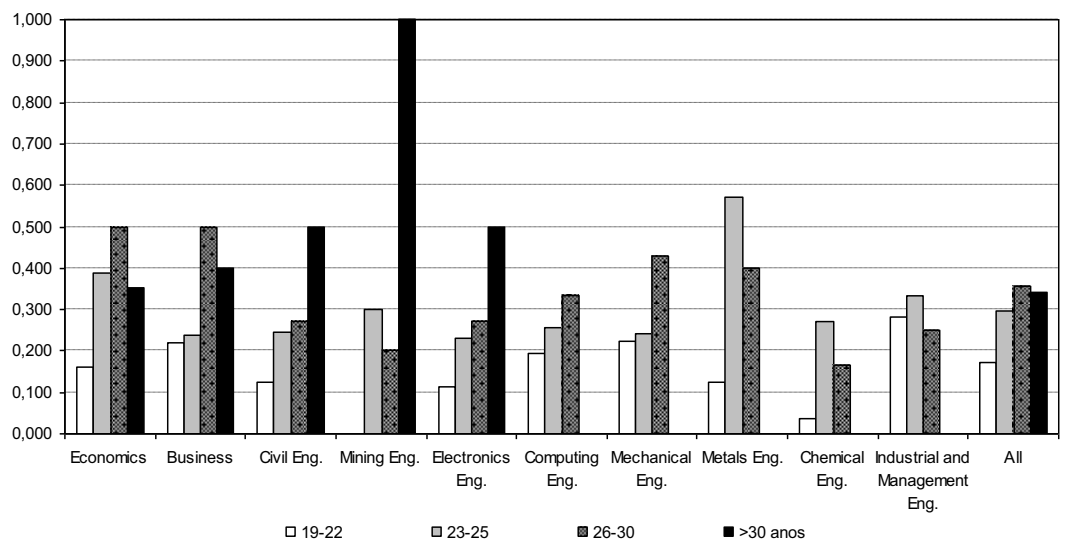

Figure 2. Entrepreneurial propensity by age and courses

At first sight, there seems to be a relationship between the status of the student, namely to be involved in academically related issues (student association members) and the desirability to be an entrepreneur. Notwithstanding, there is considerable heterogeneity among the courses analyzed, with Electronics, Computing and (utmost) Mechanical Engineering presenting the highest entrepreneurial potential by student association members. In sharp contrast, in Business the highest potential is associated with 'ordinary' enrolled students.

Correlating entrepreneurial potential with some psychological attributes associated with an entrepreneur (cf. Section 2) - risk taking, no fear of employment instability and uncertainty in remuneration; leadership wishes; creative focus; and innovative focus - we obtain an interesting picture by course.

Risk taking behavior was computed by considering the scores of the four items regarding the fear associated with new business formation - uncertainty in remuneration; employment instability; possibility to fail personally; possibility of bankruptcy. Firstly, dummies were computed for each item attributing 1 when the student responded small or no fear. Then we added up the four dummies and computed a new one which scored 1 if the sum variable totaled 3 or 4 .

Leadership variable was computed based on the response to the question on which occupation the student would choose in the case of employment by a third party or combining self and third party employment. We consider those that answered directors (of firms and other organizations) as having potential 'leader' behaviors.

In the case of creativity and innovation focus, the computations were based on students' answers to, respectively, desired occupation and industry where he/she would start the new business. We categorize occupation in terms of creativity potential (e.g., architecture, design, arts) and sectors by degree of technology intensity (cf. OECD, 1981) and knowledge intensity.

As is apparent in Figure 3, the highest entrepreneurial potential is associated with entrepreneurial traits such as risk, leadership and creativity but not so much for innovativeness. 


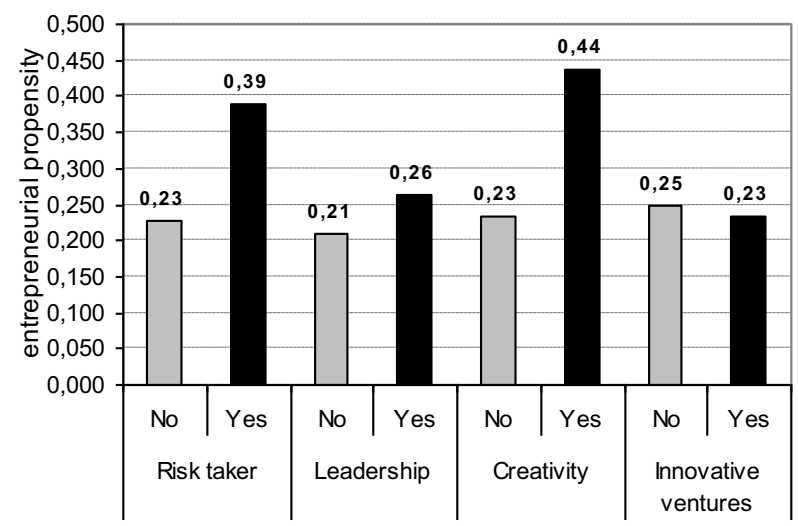

Figure 3. Entrepreneurial propensity by student psychological traits

In courses such as Economics, Civil Engineering, Electronics, and Industrial and Management Engineering, students presenting higher risk behavior, leadership traits, focus on creativity and innovative sectors reveal, on average, higher entrepreneurial potential. Nevertheless, risk behavior is associated with low entrepreneurial propensity in Mechanical and Metal courses; in Business and Metal Engineering leadership traits are essentially associated with non entrepreneurs; creativity is negatively associated with entrepreneurial potential in Mining, Mechanical, Metal and Chemical industries, which, given their business focus, is not really surprising. More surprising is the fact that focus on innovative sectors is not associated with entrepreneurial propensity in the Computing course.

The role of experience at the level of associations, and other extra curricula activities, having international experiences and professional activity experience is mixed with regard to entrepreneurial potential. On the whole, international experience is associated with higher entrepreneurial potential, whereas professional experience emerges negatively related to that potential - the only exceptions are Economics, Mining and Industrial and Management Engineering. Other extra curricula activities do not seem to impact on entrepreneurial potential, though there seems to be a strong positive correlation between these two variables in Mining, Mechanical and Metal Engineering. As stressed in the literature, other context variables, such as family background, emerge here as an important factor associated with entrepreneurial potential - particularly in Mining, Electronics, Chemical and Industrial and Management Engineering.

\section{ESTIMATION MODEL AND RESULTS}

Considering all (2430) final year students, on average, 26.5\% stated that after graduation they would like to start their own business or be exclusively self-employed. Around $56 \%$ are female and have an average age of 23 . The vast majority (over $80 \%$ ) are ordinary students and live in the North region. Only a small percentage of students (8\%) may be classified as risk prone (no or little fear of employment instability, uncertainty in remuneration, and failure). Over a third (35.7\%) present a leadership conduct, admitting that if they could choose an occupation, they would like to be firm or other organization's directors/CEOs. Although 51.3\% would invest in high-tech or high knowledge intensive 
industries in the event of starting a new business, only $14.2 \%$ would invest in creative industries. On average, students present a reasonable academic performance (with an expected grade of 13 out of 20 ), the majority (53.3\%) have or had some professional activity, $29.4 \%$ were or are involved in extra curricula activities, and a few (17\%) had some sort of international experience (e.g., Erasmus mobility program). More than half $(54.5 \%)$ have close relatives that are entrepreneurs. Economics/Business and Engineering encompass around $40 \%$ of total students, with similar shares $(20 \%)$.

In both models (Table 2 - Model I, which includes students from 60 majors, and Model II, which restricts the analysis to economics/business and engineering students), females reveal a much lower propensity for entrepreneurship. This ties in with other studies (e.g., Martínez et al., 2007), which indicate that entrepreneurship activities are more related to males. Nevertheless, it contrasts, to a certain extent, with the study of Ede et al. (1998), who found no difference between male and female African American students in their attitudes toward entrepreneurship education. All other characteristics and determinants being constant, and similarly to Ede et al. (1998), more senior students are more likely to be a potential entrepreneur. Student status only emerges as a relevant determinant of entrepreneurial propensity for the restricted model. However, the estimate indicates that among business/economics and engineering students, normal or ordinary students (i.e. full-time students) tend to be more entrepreneurially driven. Regional origin of the student does not seem to impact on the propensity which might be at least in part be explained by the fact that the vast majority (almost 90\%) live in the North (the region where the University of Porto is located). 


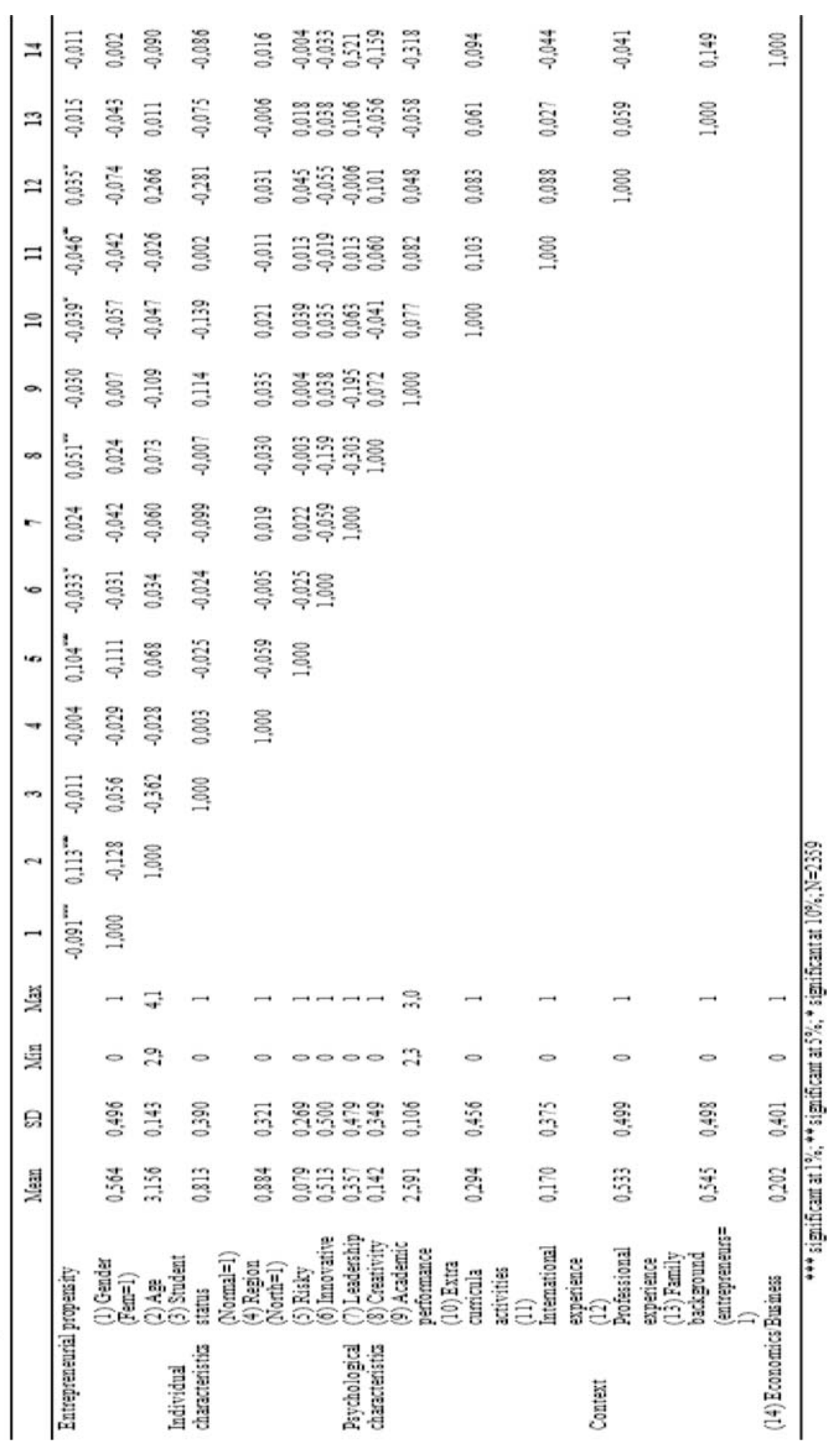


Table 2. Determinants of students' entrepreneurial propensity (Logistic model)

Model I $\quad$ Model II

\begin{tabular}{|c|c|c|c|}
\hline \multirow{5}{*}{$\begin{array}{l}\text { Individual } \\
\text { characteristics }\end{array}$} & (1) Gender $(\mathrm{Fem}=1)$ & $-0,437^{* * * * *}$ & $-0,630^{\text {***** }}$ \\
\hline & (2) Age & $1,440^{* * *}$ & $1,978^{* * *}$ \\
\hline & (3) Student status & & \\
\hline & & 0,209 & 0,471 \\
\hline & (4) Region (North=1) & 0,047 & 0,279 \\
\hline \multirow{5}{*}{$\begin{array}{l}\text { Psychological } \\
\text { characteristics }\end{array}$} & (5) Risky & $0,700^{* * *}$ & $0,576^{* *}$ \\
\hline & (6) Innovative & $-0,104$ & $-0,064$ \\
\hline & (7) Leadership & $0,277^{* *}$ & $0,580^{* * *}$ \\
\hline & (8) Creativity & $0,291^{* *}$ & $1,152^{* * *}$ \\
\hline & (9) Academic performance & $-0,623$ & $-1,421^{*}$ \\
\hline \multirow{4}{*}{$\begin{array}{l}\text { Contextual } \\
\text { factors }\end{array}$} & (9) Extra curricula activities & $-0,143$ & 0,063 \\
\hline & $\begin{array}{l}\text { (10) International } \\
\text { experience } \\
\text { (11) Professional }\end{array}$ & $-0,277^{* *}$ & $-0,305$ \\
\hline & $\begin{array}{l}\text { experience } \\
\text { (12) Family backoround }\end{array}$ & 0,054 & 0,110 \\
\hline & (entrepreneurs $=1$ ) & $-0,063$ & 0,250 \\
\hline \multicolumn{2}{|c|}{ (13) Economics/Business } & $-0,270^{*}$ & $-0,039$ \\
\hline \multicolumn{2}{|c|}{ (14) Engineering } & $-0,381^{* * *}$ & \\
\hline \multicolumn{2}{|l|}{ Constant } & $-3,438^{*}$ & $-4,089$ \\
\hline \multicolumn{2}{|l|}{$\bar{N}$} & 2359 & 971 \\
\hline \multicolumn{2}{|c|}{ Entrepreneurs } & 623 & 237 \\
\hline \multicolumn{2}{|l|}{ Others } & 1710 & 734 \\
\hline \multicolumn{4}{|c|}{ Goodness of fit statistics } \\
\hline \multicolumn{2}{|l|}{$\%$ corrected } & 73.9 & 75.8 \\
\hline \multicolumn{2}{|c|}{ Hosmer and Lameshow test (p-value) } & $4.359(0.823)$ & $2.635(0.955)$ \\
\hline
\end{tabular}

Psychologically related factors, namely risk propensity, leadership behavior and creativity focus, emerge as critical for explaining students' entrepreneurial intent. The main differences between potential entrepreneurs and other students are observed in risk bearing, leadership, and creativity focus. In these competences the scores of potential entrepreneurs are much higher than those of the remaining students. The expected average grade depicts a negative relation with entrepreneurial propensity in Model II. This means that, all else being equal, on average, for economics/business and engineering students, those that evidence better academic performance are less likely to become an entrepreneur. In part this might be explained by the fact that in Portugal, the traditional employment hunt by firms is based on grades, making those 'good' students not so eager to pursue their own venture.

Surprisingly, none of the contextual factors turn out to be relevant. In contrast to some previous evidence (e.g., Martínez et al., 2007), potential entrepreneurs do not differ from other students in the time they spend on other activities. Controlling for individual and psychological factors, potential entrepreneurs and others spend a similar amount of time working to acquire professional experience, and on extra curricula activities. Moreover, the role model stressed by the literature concerning the importance of family and contextual background does not prove to be important in this study. We do not confirm, 
therefore, the results of other entrepreneurship studies (Brockhaus and Horwitz, 1986; Brush, 1992; Cooper, 1986; Krueger, 1993), which found that students from families with entrepreneurs have a more favorable attitude toward entrepreneurship than those from non-entrepreneurial backgrounds.

Finally, controlling for all the variables likely to impact on entrepreneurial propensity, Model I shows that Economics/Business and Engineering students are less prone to entrepreneurial intents than students from other majors such as arts, life sciences or sports, to name but a few. This result proves to be quite unfortunate given the focus that previous studies on entrepreneurship placed on these two majors, and the fact that a substantial part of entrepreneurial education is undertaken in business schools (Levenburg et al., 2006). Additionally, no differences emerge (Model II) between Economics/Business and Engineering majors with regard to entrepreneurial propensity.

\section{CONCLUSIONS}

In this paper, the entrepreneurial intentions of undergraduates in Portugal are examined along with their related factors. The findings have insightful implications for researchers, university educators and administrators as well as government policy makers. First, the entrepreneurial propensity of undergraduates in Portugal is reasonably high (around 25\%) and mirrors the findings of their European counterparts (e.g., Germany, Austria).

Although a reasonable amount of students in Portugal would like to run their own businesses, their intentions are hindered by inadequate preparation. They recognize that their business knowledge is insufficient.

Second, two demographic factors - gender, age - and four psychological traits - risk, leadership, creativity and academic performance - are found to significantly affect interests in starting one's own business, while contextual factors, such as family background, are found to have little independent effect.

Notwithstanding these results, we do agree with Hatten and Ruhland (1995) and Kent (1990) when they claim that more people could become successful entrepreneurs if more potential entrepreneurs were identified and nurtured throughout the education process. The former authors demonstrate that students were more likely to become entrepreneurs after participation in an entrepreneurially related program. In this context, and as Kolvereid and Moen (1997) suggest, entrepreneurship, at least to some extent, might be a function of factors which can be altered through education.

\subsection{Acknowledgments}

The author would like to thank the Rector of the University of Porto (UP), the Deans of the 14 Schools of the University, and professors/lecturers for their support for this research. Thanks to José Mergulhão Mendonça (FEP Computing Center) and André Rosário (MIETE Master Student) for their valuable assistance in the implementation of the survey. A word of profound recognition to all students of UP. 


\section{REFERENCES}

1. Baucus, D., Human, S. Second-career entrepreneurs: A multiple case study analysis of entrepreneurial processes and antecedent variables. Entrepreneurship Theory and Practice 1995; 19(4): 41-72.

2. Brandstätter, H. Becoming an entrepreneur - a question of personality structure?. Journal of Economic Psychology 1997; 18: 157-177.

3. Brockhaus. R. H.. Jr., Horwitz, P. S. "The psychology of the entrepreneur". In The art and .science of entrepreneurship, D. L. Sexton \& R. W. Smilor (Eds.), Cambridge. MA: Ballinger, 1986, pp. 25-48.

4. Brush, C. Research of women business owners: past trends, a new perspective, future directions". Entrepreneurship Theory and Practice 1992; Vol. 16: pp.5-30.

5. Carland, J. W.. Hoy, F.. Boulton. W. R., \& Carland. J. Differentiating entrepreneurs from small business owners: A conceptualization. Academy of Management Review 1984; 9: 354-359.

6. Carroll, G., Mosakowski, E. The career dynamics of self-employment. Administrative Science Quarterly 1987; 32: 570-589.

7. Cooper, A. "Entrepreneurship and high technology". In The art and science of entrepreneurship, D. Sexton \& R. Smilor (Eds.), Cambridge, MA: Ballinger Publishing, 1986, pp. 153-180.

8. Delmar, F., Davidsson, P. Where do they come from? Prevalence and characteristics of nascent entrepreneurs, Entrepreneurship \& Regional Development 2000; 12: pp. 1-23.

9. DeMartino, R., Barbato, R. An Analysis of the Motivational Factors of Intending Entrepreneurs. Journal of Small Business Strategy 2002.

10. Dyer, W.G. Toward a theory of entrepreneurial careers. Entrepreneurship, Theory and Practice 1994; Vol. 19 No. 2: pp. 7-21.

11. Ede, Fred O., Panigrahi, Bhagaban, Calcich, Stephen E., African American students' attitudes toward entrepreneurship. Journal of Education for Business 1998; May/Jun98, Vol. 73, Issue 5.

12. European Commission. Toward enterprise eEurope: work programme for enterprise policy 2000-2005: Commission staff working paper. Document No., 2000.

13. Franke, N., Lüthje, C. Entrepreneurial Intentions of Business Students: A Benchmarking Study. International Journal of Innovation and Technology Management 2004; vol. 1(3): 269-288

14. GEE. Temas Económicos. Empreendedorismo, Lisboa: Ministério da Economia e da Inovação, Gabinete de Estratégia e Estudos, 2005.

15. Greenberger. D. B., \& Sexton. D. L. An interactive model of new venture creation. Journal of Small Business Management 1988; 26(3): 107.

16. Greene, W.H. Econometric Analysis, Prentice Hall, 2000.

17. Gürol, Y. ve Atsan, N. Entrepreneurial characteristics amongst university students: some insights for enterprise education and training in Turkey. Education and Training 2006; Vol. 48, No. 1: 25-39.

18. Hatten, T.S., Ruhland, S. K. Student attitude toward entrepreneurship as affected by participation in an SBI program. Journal of Education for Business 1995; 70(4): 224-227.

19. Henderson, R., Robertson, M. Who wants to be an entrepreneur? Young adult attitudes to entrepreneurship as a career. Education \& Training 1999; 41(4/5): 236-246.

20. Hills, G. E., Barnaby, D. J. Future entrepreneurs from the business schools: Innovation is not dead. In Proceedings of the 22nd International Council for Small Business, Washington, DC: International Council for Small Business, 1977, pp. 27-30.

21. Hills, G.E., Welsch, H. "Entrepreneurship behavioral intentions and student independence, characteristics and experiences". In Frontiers of Entrepreneurship Research: Proceedings of the Sixth Annual Babson College Entrepreneurship Research Conference, Babson Park, MA: Babson College, 1986, pp. 173-186.

22. Hisrich, R. D. Entrepreneurship: Past, present, and future. Journal of Small Business Management 1988; 26(4): 1-4.

23. Hosmer, D., Lemeshow, S. Applied Logistic Regression, New York: John Wiley \& Sons, 1989.

24. Hynes, B. Entrepreneurship education and training: Introducing entrepreneurship into non-business disciplines. Journal of European Industrial Training 1996; 20(8): 10-17.

25. Kent, C. A. "Introduction: Educating the heffalump". In Entrepreneurship education: Current developments, future directions, C. A. Kent (Ed.), New York: Quorum, 1990, pp. 1-27.

26. Klapper, R., Léger-Jarniou, C. Entrepreneurial intention among French Grande École and university students: an application of Shapero's model. Industry \& Higher Education 2006; April: 97-110.

27. Kolvereid, L., Moen, Ø. Entrepreneurship among business graduates: does a major in entrepreneurship make a difference?. Journal of European Industrial Training 1997; Vol. 21(4): 154.

28. Kourilsky, M.L., Walstad, W.B. Entrepreneurship and female youth: Knowledge, attitudes, gender differences and educational practices. Journal of Business Venturing 1998; 13: 77 - 88.

29. Krueger, N. The impact of prior entrepreneurial exposure on perceptions of new venture feasibility and desirability. Entrepreneurship theory and practice 1993; Fall: 5-21.

30. Krueger, N., Reilly, M., Carsrud, A. Competing models of entrepreneurial intentions. Journal of Business Venturing 2000; Vol. 15: 411-432.

31. Learned, K.E. What happened before the organization? A model of organization formation. Entrepreneurship theory and practice $1992 ; 17(1): 39-48$ 
32. Lena, L., Wong, P.K. Attitude towards entrepreneurship education and new venture creation. Journal of Enterprising Culture 2003; Vol. 11 (4): 339-357.

33. Levenburg, N., Lane, P., Schwarz, T. Interdisciplinary Dimensions in Entrepreneurship. Journal of Education for Business 2006; May-June: 276-281.

34. Lissy, D. Goodbye b-school. Harvard Business Review 2000; 78(2): 16-17.

35. Lüthje, C., Franke, N. The 'Making' of an Entrepreneur: Testing a Model of Entrepreneurial Intent among Engineering Students at MIT. R\&D Management 2003; 33, p. 2.

36. Martínez, D. Mora J.-G., Vila, L. Entrepreneurs, the Self-employed and Employees amongst Young European Higher Education Graduates. European Journal of Education 2007, Vol. 42, No. 1, pp.

37. McClelland, D.C. The Achieving Society. Van Nostrand, Princeton, NJ, 1961.

38. McFarlane, Carolyn. Stimulating Entrepreneurship Awareness in High School Students. Journal of Career Education 1981, pp. 135-144.

39. Naffziger, D.W., Hornsby, J.S., Kurtako, D.F. A proposed research model of entrepreneurial motivation. Entrepreneurship Theory and Practice 1994; 18(3): 29-42

40. Oakey, R., Mukhtar, S-M., Kipling,M. "Student perspectives on entrepreneurship: observations on their propensity for entrepreneurial behaviour". 2002, Vol. 2 (4/5): 308-322

41. OECD. Science and Technology Policy for the 1980s. Paris, 1981.

42. Reynolds, P.D. Who starts new firms? Preliminary explorations of fFirms-in-Ggestation. Small Business Economics 1997; 9: 449-462.

43. Robinson, P.B. Prediction of entrepreneurship based on attitude consistency model. Unpublished doctoral dissertation, Brigham Young University. Dissertation Abstracts International 1987, 48, 2807B.

44. Sagie, A., Elizur, D. Achievement motive and entrepreneurial orientation: a structural analysis. Journal of Organizational Behavior 1999; Vol. 20 No. 3: 375-87.

45. Scott, A. J. New Industrial Spaces. London: Pion, 1988.

46. Scott, M.G., Twomey, D.F. The long-term supply of entrepreneurs: students' career aspirations in relation to entrepreneurship. Journal of Small Business Management 1988, pp.5-13.

47. Sexton, D.L., Bowman, N.B. "Comparative entrepreneurship characteristics of students: preliminary results". In Frontiers of Entrepreneurship Research, Hornaday, J., Timmons, J., Vesper, K. (Eds). Babson College, Wellesley, MA, 1983, pp.213-32.

48. Stewart Jr., W.H., Watson, W.E., Carland, J.C., Carland, J.W. A proclivity for entrepreneurship: a comparison of entrepreneurs, small business owners, and corporate managers. Journal of Business Venturing 1998; 14: 189-214.

49. Storey, D. J. Understanding the Small Business Sector. London, Routledge, 1994.

50. Teixeira, A.A.C. "Beyond economics and engineering: the hidden entrepreneurial potential", mimeo, Faculdade de Economia, Universidade do Porto, 2007.

51. Teixeira, A.A.C. "From economics, business and engineering towards law, medicine and sports: a comprehensive survey on the entrepreneurial potential of university students", Seminar at EEG, Universidade do Minho, 30 March 2007.

52. Van Auken, H., Stephens, P., Fry F., Silva J. Role model influences on entrepreneurial intentions: A comparison between USA and Mexico. Entrepreneurship Management 2006; Vol. 2: 325-336 